\title{
Penentuan Vektor Malaria di Kabupaten Keerom, Papua
}

\author{
Malaria Vector Incrimination in Keerom Regency, Papua \\ Ign. Joko Suyono $^{1 *}$, Dirk Runtuboi ${ }^{1}$, Aditya Krishar Karim ${ }^{1}$, dan Sigit Raharjo ${ }^{2}$

 \\ ${ }^{2}$ Departemen Dinas Kesehatan Jayapura, Papua \\ E-mail: ignetds@yahoo.com*Penulisuntukkorespondensi
}

\begin{abstract}
Malaria is one of the major threats concerning world public health especially in the tropical countries, where bear the major burden of the disease, such as in Papua. Malaria was transmitted by Anopheles mosquito as malaria vector. This research aimed to determine and identify the malaria vector in Keerom Regency. Vector status was determined by the value of vector capacity or sporozoite content in Anopheles mosquito. Mosquitoes composition in the location of study were An. koliensis, An. farauti, An. punctulatus, An. subpictus dan An. brancroftii. An. subpictus and $A$. brancroftii were only found in a few number of individual so they were not included in vectorial capacity analysis. The result of vector capacity analysis showed that An. koliensis range from $6 \%$ to $17 \%$, An. farauti range from $0.3 \%$ to $3 \%$, and $A n$. punctulatus range from $3 \%$ to $5 \%$. Sporozoite detection using VecTOR ${ }^{\mathrm{TM}}$ Test showed that sporozoite was not found in the mosquitoes being studied. The potential malaria vectors in Keerom regency were $\boldsymbol{A n}$. koliensis, An. punctulatus and An. farauti.
\end{abstract}

Keywords: Malaria vector, vector capacity, Anopheline mosquito, sporozoite, $\operatorname{VecTOR}^{\mathrm{TM}}{ }^{\mathrm{Test}}$

Abstrak

Malaria merupakan salah satu masalah kesehatan utama di beberapa wilayah didunia terutama di wilayah tropis seperti halnya di Papua. Malaria disebabkan oleh nyamuk Anopeles sebagai vektor malaria. Tujuan penelitian ini adalah menentukan dan mengidentifikasikan kemampuan nyamuk Anopheles menularkan penyakit malaria di Kabupaten Keerom. Status vektor ditentukan berdasarkan kapasitas vektorial atau pendeteksian kandungan sporozoit pada nyamuk Anopheles. Komposisi nyamuk yang ditemukan di lokasi penelitian adalah $A n$. koliensis, An. farauti, An. punctulatus, An. subpictus dan An. brancroftii. An. subpictus dan An. brancroftii hanya ditemukan dalam jumlah yang kecil sehingga tidak dilakukan analisis kapasitas vektorial. Perhitungan kapasitas vektorial menunjukkan bahwa kapasitas vektorial An. koliensis berkisar dari $6 \%$ dan $17 \%$, An. farauti antara $0,3 \%$ dan $3 \%$, dan An. punctulatus berkisar antara $3 \%$ dan $5 \%$. Deteksi kandungan sporozoit menggunakan Test VecTOR ${ }^{\mathrm{TM}}$ menunjukkan tidak ditemukannya sporozoit pada nyamuk yang diteliti. Potensi nyamuk yang diduga merupakan vektor malaria di Kabupaten Keerom adalah An. koliensis, An. punctulatus dan An. farauti.

Kata kunci: Vektor malaria, kapasitas vektorial, nyamuk Anopheles, sporozoit, VecTOR $^{\mathrm{TM}}{ }^{\mathrm{Test}}$ 